\title{
The exhumation rate of Dabie orogen: Evidence from garnet diffusion zoning
}

\author{
Hao Chengt*, Daogong Chenł, and Etienne Deloules \\ † School of Ocean and Earth Science, Tongji University, Shanghai, PR CHINA \\ $¥$ School of Earth and Space Sciences, University of Scicence and Technology of China, Hefei,PR CHINA \\ \$ CRPG-CNRS, Nancy, FRANCE
}

*Towhom correspondence should be addressed.E-mail: chenghao@mail.tongji.edu.cn

Dabie-Sulu terrain is a joint suture formed by Triassic collision between the northern margin of Yangtze craton with southern margin of Sino-Korean craton. Coesite and diamond-bearing eclogites and other UHP/HP rocks have been discovered there, and it is thought to be the largest HP-UHP terrain all over the world. From north to south, Dabie terrain is separated into four different petro-tectonic unites by two NW and EW trend fault systems: the Northern Huaiyan, Northern Dabie metamorphic complex, Southern Dabie UHP metamorphic belt and Susong metamorphic complex (Liou et al. 1995). Okay (1993) divided Southern Dabie into northern hot eclogite and southern cold eclogite zone based on metamorphic temperature and pressure. Coesite-bearing hot eclogite has higher PT as to $640^{\circ} \mathrm{C}$ and $27-40$ kbar and cold eclogite has lower PT as to $580-635^{\circ} \mathrm{C}$ and $20-24$ kbar, which contain no coesite and underwent only HP metamorphism (Carswell et al. 1997). Sulu HP-UHP terrain is believed as the eastern extension of Dabie terrain translated by Tanlu fault. Our samples were collected from this orogen, which are Bixiling (BXL) eclogites, the largest coesite-bearing garnet peridotite-eclogite complex in Southern Dabie UHP terrain; JInheqiao(JHQ) eclogites is in south side of Bixiling eclogite; Qinglongshan (QLS) eclogite is in Southern end of Sulu terrain,Donghai; Huangzhen (HZ) eclogites locate at the boundary between Southern Dabie UHP terrain and Susong HP terrain in Taihu, which is cold eclogite. Raobazhai (RBZ) eclogite is an ultramafic-eclogite complex, Nothern Dabie metamorphic zone. It has granlulite regression after elcogite peak metamorphism. Huangtuling (HTL) granulite and acidic granulite from Luotian Hubei belongs to west part of Northern Dabie Terrain, the core of Luotian complex. Except for HTL granulite, the above five rocks are believed to be involved in Triassic HP-UHP metamorphism.

Based on diffusion theory we analyzed garnet zoning for these six HP-UHP metamorphic rocks from Dabie and modeled these different diffusion zoning, followed the methods by Duchene et al. (1998), Lommis et al. (1975), Perchuk et al. (2002), Lasaga (1983) and Ganguly et al. (2000). The estimated peak metamorphic temperature and pressure, and calculated cooling rate from different diffusion models for garnets are described in Figure 1. Since the meaning lowest temperature for $\mathrm{Fe}, \mathrm{Mg}$ ion exchange between garnet and other minerals is around $500^{\circ} \mathrm{C}$, the cooling rate obtained by garnet diffusion usually means its average values for duration from peak metamorphic temperature to about $500^{\circ} \mathrm{C}$. From Figure 1 we can see that the cooling rate for BXL eclogite was more than $20^{\circ} \mathrm{C} / \mathrm{Ma}$ at beginning, and it has decreased to less than $10^{\circ} \mathrm{C} / \mathrm{Ma}$ with time at $500^{\circ} \mathrm{C}$; JHQ eclogite shows similar zoning pattern with BXL eclogite and its average cooling at rate of about $20-30^{\circ} \mathrm{C} / \mathrm{Ma}$ within 10 Ma duration; Garnet modeling for QLS eclogite reveals a faster than $20^{\circ} \mathrm{C} / \mathrm{Ma}$ cooling rate. The cooling rate for Dabie and Sulu UHP hot eclogites is comparable. HZ eclogite showed that the adjustment of zoning lasted $20 \mathrm{Ma}$ at an average cooling rate of $8^{\circ} \mathrm{C} / \mathrm{Ma}$ after peak temperature. The special zoning for RBZ eclogite was caused by new formed component across a tiny crack diffusion adjustment with the previous garnet parts. The result shows it cooled down to $700^{\circ} \mathrm{C}$ at rate of about $25^{\circ} \mathrm{C} / \mathrm{Ma}$, similar to that of hot eclogite at initial cooling. HTL granulite, different from eclogite, exhumed up to mid-low crust with isothermal depression(ITD) after peak granulite metamorphism and stay

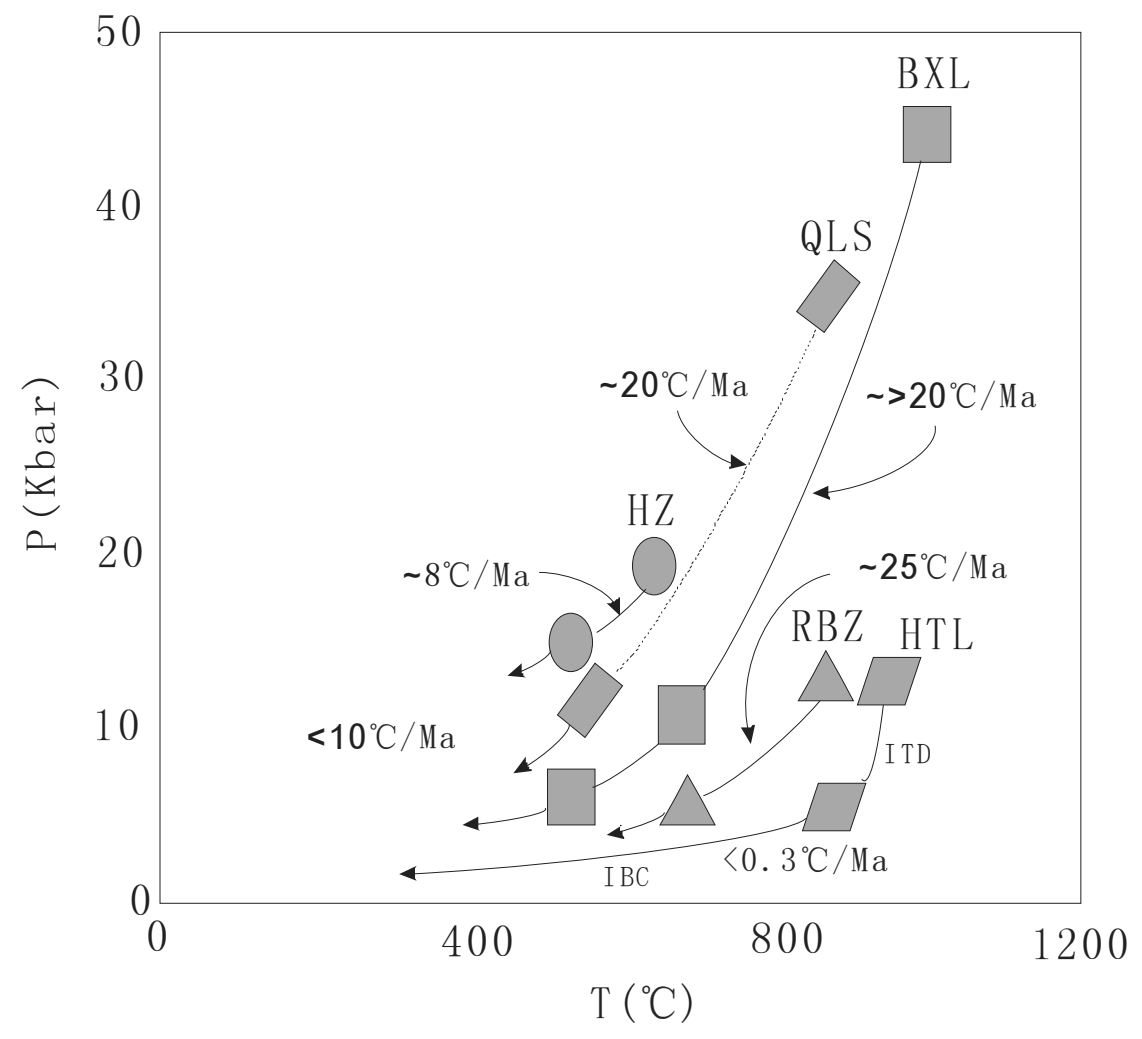

FIGURE 1. Cooling rate of eclogites from Dabie orogen 
there for quite long and then its cooling was very slow as to less than $0.3^{\circ} \mathrm{C} / \mathrm{Ma}$ without pressure decreasing (IBC) until its exposure to surface by erosion. The rock was not involved in deep subduction unit.

Cooling and exhumation of Dabie orogen rocks by using age data also have very large variations by geochronology. Hacker et al. (2000) obtained an average vertical exhumation rate larger than $2 \mathrm{~km} / \mathrm{Ma}$ for Dabie-Hongan terrain; Ayers et al. (2002) calculated exhumation rate of 7.1-8.0 km/Ma for Maowu eclogite and only $1.0 \mathrm{~km} / \mathrm{Ma}$ for Shuanghe UHP rock. Li et al. (2000) released a cooling of $40^{\circ} \mathrm{C} / \mathrm{Ma}$ for Shuanghe slate. Based on garnet diffusion kinetics data we acquired approximately similar cooling rates for different petro-tectonic unit of Dabie-Sulu orogen. It is indicated that HP-UHP rocks from Southern Dabie, Northern Dabie and Sulu belong to a coherent orogenic terrain and are product within one episodic event. Even at above $500^{\circ} \mathrm{C}$, the cooling rate of eclogite is still keep such a process from fast to slow. According to age data of $\mathrm{HZ}$ eclogite, we calculated average exhumation of $1.5 \mathrm{~km} / \mathrm{Ma}$. Obviously, the obtained cooling and exhumation rate is similar to that of Hacker et al. (2000) for Dabie-Sulu and Ayers et al. (2002) for Shuanghe, but not for Maowu. Compared to Alps and Kazakstan UHP rocks, most of Dabie-Sulu data show relative slower cooling and exhumation rates. Different cooling and uplift reflect different exhumation mechanism, like plate break off, buoyancy and fast erosion. If the exhumation for Dabie rocks is definitely distinguished from that of Alps and Kazakstan, then their tectonic evolution should be different. Study on exhumation rate by modelling of garnet diffusion zoning and geochronology could and should be comparable and complement as well as validate each other.

\section{References}

Carswell D, O'P Brien, and RWilson. 1997. Thermobarometry of phengitebearing eclogites in the Dabie mountains of central China. J.Metamor Geol 15: 239-252

Duchêne S, S Albarede, and J Lardeaux. 1998. Mineral zoning and exhumation history in the Munchberg eclogites (Bohemia). AmerJ Sci. 298: $30-59$

Ganguly J, S Dasgupta, andW Cheng. 2000. Exhumation history of a section of the Sikkim Himalayas, India: records in the metamorphic mineral equilibris and compositional zoning in garnet. Earth Planet Sci Lett 183: $471-486$

Lasaga AC, SM Richardson, and HD Holland. 1977. The mathematics of cation diffusion and exchange between silicate minerals during retrograde metamorphism . In: Saxena S K.,Bhattacharji, (eds) Energetics of Geological Processes. Springer,Berlin. 353-388

Liou JG, and R Zhang. 1995. Significance of ultrahigh-P talc-bearing eclogites assembles. Mineral Mag 59: 93-102 